\title{
Methodology of actors analysis and modeling of the amounts of solid municipal waste generation within tourist destinations
}

\author{
Iuliia Iuras $^{1 *}$, Petro Raiter ${ }^{2}$, Yaroslava Korobeinykova ${ }^{1}$, Liubov Poberezhna $^{3}$ \\ ${ }^{1}$ Department of Tourism, Ivano-Frankivsk National Technical University of Oil and Gas, Ivano-Frankivsk, Ukraine \\ *Email: iuliia.murava@ukr.net \\ ${ }^{2}$ Department of Technical Diagnostics and Monitoring, Ivano-Frankivsk National Technical University of Oil and Gas, \\ Ivano-Frankivsk, Ukraine \\ ${ }^{3}$ Department of Medical Informatics, Medical and Biological Physics, Ivano-Frankivsk National Medical University, \\ Ivano-Frankivsk, Ukraine
}

Received: 28 August 2019 / Accepted: 14 April 2020

\begin{abstract}
The article presents the results of the study of factors influencing the amount of waste generated within tourist destinations. By means of dispersion and regression analysis functional dependencies were established. They allowed determining the connection between the factors and amounts of waste generation within tourist destinations. The established functional dependencies allowed forecasting the amount of waste generation within the territories of tourist activities. The authors determined that the factors influencing the amount of waste generated within tourist destinations are the number of tourists and excursionists, GDP per capita, number of population. 3D surfaces built in the program Surfer made it possible to assess the influence of different combinations of factors on the process of waste generation. A mathematical model of the process of waste generation within the territories of tourist destinations was built in order to help to create efficient waste management systems within the territories of tourism development.
\end{abstract}

Keywords: ecological safety, waste management, solid municipal waste, impact of tourism on the environment, sustainable development.

\section{Introduction}

Nowadays tourism is a successful branch of the economy in the world, which is developing steadily. Despite its significant positive economic and social impact, tourism also has a number of negative impacts on the environment. According to international experts the share of tourism in environmental degradation is $5-7 \%$ (Sli, 2000). Rapid uncontrolled development of tourism industry, development of tourism infrastructure, increase and uneven distribution of tourist flows in time and space have a negative impact on water resources, soils, flora, fauna, etc.
The main directions of the environmental impact of tourism are water pollution, energy consumption and waste management. Waste management within tourist destinations in Ukraine is the least studied and insufficiently solved direction of impact on the environment. The need to implement environmentally friendly and effective waste management methods within tourist destinations is particularly relevant due to the fact that the number of tourists is increasing each year and during "high seasons" significantly exceeds the number of local population. Sustainable development within the territories of the arrival and location of tourists (tourist destinations) is very important as 
tourism industry depends on the condition of the environment more than other branches of the economy.

Environmental aspects of tourism industry are studied by Ukrainian scientists in the context of sustainable tourism development. Main directions of tourism impact on the environment, development of directions for ensuring sustainable tourism development (Murava \& Korobeinykova, 2016; Zinko et al., 2014), and directions, requirements, and methods for ensuring ecological safety within tourist destinations (Vorobiova, 2011; Holod \& Novosad, 2012; Myronova \& Panova, 2007; Sharko, 2014) were studied and analyzed in the works of many scientists.

Issues of waste according to the fields of its generation and operation of landfills were studied by such Ukrainian scientists as O.I. Fedorenko (environmental impact of waste), T.P. Shanina, O.R. Hubanova, V.H. Petruk (issues of waste management), M.S. Malovanyi, V.M. Radovenchyk, M.D. Homelia, M.B. Korbut, H.S. Bilyk (ecological safety of solid municipal waste landfills), M.M. Orfanova (ecological and technological principles of waste management), I.H. Kotsiuba (factors that influence the amount of solid waste generation) and others. However, the issues of waste management within tourist destinations are practically unstudied in Ukraine. The world scientific community carried out such studies within the United Nations Environment Program (UNEP) (A Manual for Water and Waste Management, 2017). A number of scientists also studied such problems, e.g., main directions of the impact of tourism and hotel industry on the environment (Holden, 2006; Davies \& Cahill, 2000), waste management in small hotel facilities (Radwan et al., 2010), waste management within the territories of rural tourism development (Nair \& Jayakumar, 2008), impact of tourism on the amount of generated waste (Mateu-Sbert et al., 2013), EU countries experience in the field of waste management in tourist destinations (Ezeah et al., 2015).

Existing studies of the factors that influence the amount of waste generation outline the problem only in general without studying them according to the field of waste generation, and therefore almost completely ignore the nega- tive impact of tourism on the amount of waste generation. Ukrainian scientists outlined such factors that influence the amount of waste generation in Zhytomyr (Ukraine) as the number of population, housing, number of retail sales, amount of industrial production, and income of inhabitants (Kotsiuba, 2014).

Japanese researchers in the study of the problem of waste management in developing countries determined such municipal solid waste generation factors as urbanization, GDP per capita, illiteracy / level of public awareness, sanitary services (Khajuria et al., 2010). However, the specifics of most tourist destinations, which are characterized by the increase in tourist flows, indicate the need for a more detailed consideration of factors that affect the amount of waste generated within the territories of tourism development. During the study of the impact of tourism on local waste management, some researchers pointed to the impact of tourism infrastructure on waste generation and the multifactorial nature of this process (Mihai, 2013).

\section{Materials and methods}

In order to determine the impact of tourism industry on the amount of generated waste in Ivano-Frankivsk region (Ukraine) and according to the analyzed Ukrainian and foreign scientific studies the authors developed a hypothesis that the factors influencing the amount of waste generation within tourist destinations are the following (Fig. 1):

- number of tourists and excursionists (during "high" tourist seasons the number of tourists can significantly exceed the number of local population, and respectively, the amount of generated waste may increase; such strong fluctuations in the number of tourists due to the seasons complicate even more the issue of waste management system which was planned without taking into account the possible impact of tourists);

- GDP per capita (this indicator represents best the real state of the national economy and allows the most ad-

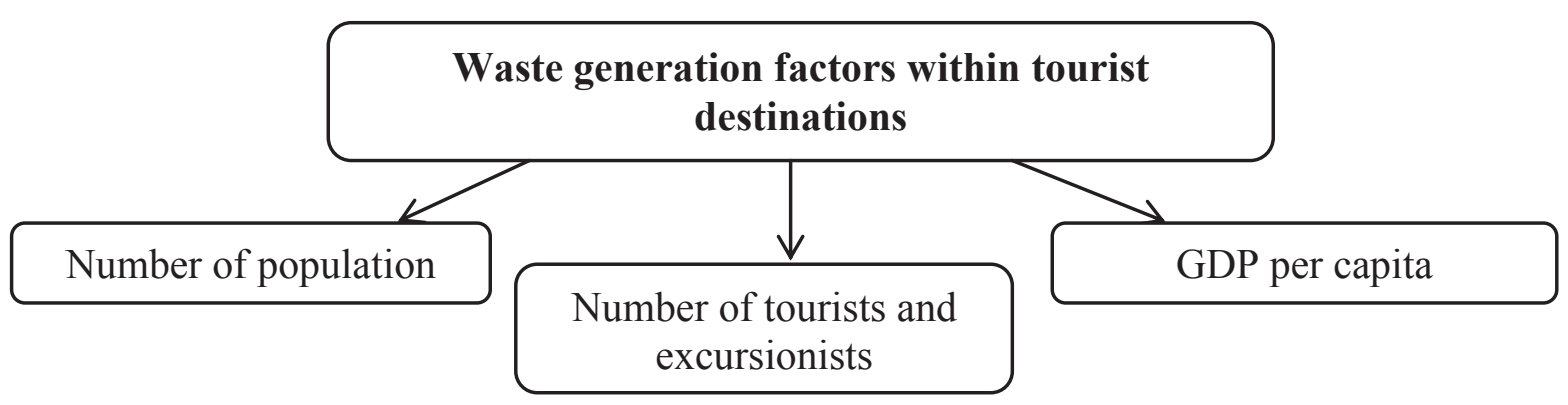

Figure 1. Waste generation factors within tourist destinations 
equate assessment of purchasing power due to the unstable economic situation that affects the amount of waste);

- number of population (local population is a stable factor of the municipal waste generation, especially in "low" tourist seasons; data on waste amount includes waste generated by both tourists and excursionists as well as local population).
To check the significance of the effect of these factors we conducted the one-factor dispersion analysis of the impact of each selected factor on the amount of generated waste.

The indicator of the generated waste amount was chosen as a resultant indicator (Y) and the following indicators were used as the factor indicators:

Table 1. Data on the influence of factors X1, X2, X3 on the amount of generated waste Y in 2000-2009

\begin{tabular}{|c|c|c|c|c|}
\hline Year & $\mathbf{Y}$ & $\mathbf{X}_{\mathbf{1}}$ & $\mathbf{X}_{\mathbf{2}}$ & $\mathbf{X}_{\mathbf{3}}$ \\
\hline $\mathbf{2 0 0 0}$ & 15.4 & 77.2 & 3.582 & 1430.1 \\
\hline $\mathbf{2 0 0 1}$ & 16.5 & 115.11 & 3.939 & 1420.2 \\
\hline $\mathbf{2 0 0 2}$ & 14.5 & 139.5 & 4.612 & 1409.7 \\
\hline $\mathbf{2 0 0 3}$ & 15.0 & 145.1 & 5.363 & 14037 \\
\hline $\mathbf{2 0 0 4}$ & 17.5 & 95.9 & 6.534 & 1397.8 \\
\hline $\mathbf{2 0 0 5}$ & 20.5 & 229.4 & 7.823 & 1393.6 \\
\hline $\mathbf{2 0 0 6}$ & 12.4 & 352.2 & 10.515 & 1388.9 \\
\hline $\mathbf{2 0 0 7}$ & 9.8 & 1781.8 & 13.147 & 1385.4 \\
\hline $\mathbf{2 0 0 8}$ & 7.0 & 1153.3 & 16.602 & 1382.6 \\
\hline $\mathbf{2 0 0 9}$ & 4.2 & 1025.0 & 18.258 & 1381.1 \\
\hline
\end{tabular}

Table 2. Data on the influence of factors X1, X2, X3 on the amount of generated waste Y in 2010-2016

\begin{tabular}{|c|c|c|c|c|}
\hline Year & $\mathbf{Y}$ & $\mathbf{X}_{\mathbf{1}}$ & $\mathbf{X}_{\mathbf{2}}$ & $\mathbf{X}_{\mathbf{3}}$ \\
\hline $\mathbf{2 0 1 0}$ & 1097.9 & 691.289 & 21.491 & 1380.7 \\
\hline $\mathbf{2 0 1 1}$ & 1576.7 & 478.690 & 25.852 & 1380.8 \\
\hline $\mathbf{2 0 1 2}$ & 1782.8 & 570.382 & 29.637 & 1380.1 \\
\hline $\mathbf{2 0 1 3}$ & 1692.6 & 535.126 & 32.090 & 1382.1 \\
\hline $\mathbf{2 0 1 4}$ & 1815.0 & 1573.91 & 31.841 & 1381.8 \\
\hline $\mathbf{2 0 1 5}$ & 2124.8 & 1850.327 & 33.419 & 1382.4 \\
\hline $\mathbf{2 0 1 6}$ & 1935.4 & 2185.014 & 47.7738 & 1382.6 \\
\hline
\end{tabular}

Table 3. Data on the influence of factors X1, X2, X3 on the amount of generated municipal solid waste Y in 2010-2016

\begin{tabular}{|c|c|c|c|c|}
\hline Year & $\mathbf{Y}$ & $\mathbf{X}_{\mathbf{1}}$ & $\mathbf{X}_{\mathbf{2}}$ & $\mathbf{X}_{\mathbf{3}}$ \\
\hline $\mathbf{2 0 1 0}$ & 191.9 & 691.3 & 21.491 & 1380.7 \\
\hline $\mathbf{2 0 1 1}$ & 216.0 & 478.7 & 25.852 & 1380.8 \\
\hline $\mathbf{2 0 1 2}$ & 204.0 & 570.4 & 29.637 & 1380.1 \\
\hline $\mathbf{2 0 1 3}$ & 217.7 & 535.126 & 32.090 & 1382.1 \\
\hline $\mathbf{2 0 1 4}$ & 208.9 & 1573.9 & 31.841 & 1381.8 \\
\hline $\mathbf{2 0 1 5}$ & 165.6 & 1850.3 & 33.419 & 1382.4 \\
\hline $\mathbf{2 0 1 6}$ & 183.4 & 2185.0 & 47.7738 & 1382.6 \\
\hline
\end{tabular}


$-\mathrm{X}_{1}$ is a number of tourists and excursionists, ths. pers.;

$-\mathrm{X}_{2}$ is GDP per capita, ths. UAH;

$-\mathrm{X}_{3}$ is a number of population, ths. pers.

The authors analyzed the statistical data on these indicators within tourist Ivano-Frankivsk region as a model one. It was collected and comprehensively processed from different sources, such as Main Statistics Services, regional Departments of Tourism, web portals, etc. The relevant databases were created according to them. Then they were used for dispersion, regression analysis and $3 \mathrm{D}$ visualization.

For more effective analysis the authors divided all statistical data into three groups:

amount of generated waste in 2000-2009 (excluding waste generated in households, since there is no statistical data on the generation of such waste in this period in Ukraine);

- amount of generated waste in 2010-2016 (including waste generated in households);

- amount of generated solid municipal waste in 2010-2016.

The complex input data for the dispersion analysis of the influence of factors on the amount of generated waste is given in Tables 1, 2, 3 (Statistical data of Ivano-Frankivsk region, 2017; Waste management in Ukraine, 2017; Gross domestic product per capita, 2017; State Statistics Service of Ukraine, 2017).

Also, authors performed a 3D visualization of the process of waste amounts changes within Ivano-Frankivsk region, taking into account the influence of the selected factors on the basis of collected statistical data. This task was implemented in the program Surfer, which allows processing and visualizing two- and three-dimensional data.

The authors also applied regression analysis on this data to determine the influence of the selected factors on the resultant indicator and establishment of functional dependencies.
Depending on the number of variables, different types of regression analysis are distinguished. Due to the nature of the connection linear and nonlinear functions can be used in the regression analysis. Effective means of implementing difficult calculations is "Data Analysis" package in MS Excel that allows performing mathematical calculations, building multi-factor linear and nonlinear models, and others. The authors used it for dispersion and regression analysis.

\section{Results and discussion}

As a result of one-factor dispersion analysis F statistics was obtained for three selected factors in the studied periods based on the data presented in Tables 1, 2, 3. It is higher than the critical indicator $\mathrm{F}$ (tabular indicator). Therefore, we can conclude that the influence of each of the factors on the amount of waste generation is significant (Table 4). The authors' hypothesis about the influence of these factors on the amount of waste generation within tourist destinations was confirmed.

Also, the authors performed a $3 \mathrm{D}$ visualization of the process of waste amounts changes within Ivano-Frankivsk region, taking into account the influence of the selected factors on the basis of the data presented in Tables 1, 2, 3. This task was implemented in the program Surfer. The built 3D surfaces allowed assessing the influence of various combinations of factors on the process of waste generation and the level of interconnection between the factors of waste generation.

As an example, let us consider the 3D-surfaces reflecting the dependence of the amount of generated waste, including solid municipal waste, on the number of tourists and excursionists, and GDP (Figs 2-4).

Table 4. Results of dispersion analysis on the influence of factors $\mathrm{X}_{1}, \mathrm{X}_{2}, \mathrm{X}_{3}$ on the amount of generated waste $\mathrm{Y}$

\begin{tabular}{|c|c|c|c|c|c|c|}
\hline \multirow{2}{*}{ Period } & \multicolumn{2}{|c|}{$\begin{array}{c}\mathbf{X}_{1} \\
\text { (number of tourists and } \\
\text { excursionists) }\end{array}$} & \multicolumn{2}{|c|}{$\begin{array}{c}\mathbf{X}_{2} \\
\text { (GDP per capita) }\end{array}$} & \multicolumn{2}{c|}{$\begin{array}{c}\mathbf{X}_{3} \\
\text { (number of population) }\end{array}$} \\
\cline { 2 - 7 } & F & F- criterion & F & F- criterion & F & F- criterion \\
\hline $\mathbf{2 0 0 0 - 2 0 0 9}$ & 7.012 & 4.414 & 28.419 & 4.414 & 64436.313 & 4.4149 \\
\hline $\mathbf{2 0 1 0 - 2 0 1 6}$ & 4.925 & 4.747 & 188.974 & 4.747 & 7.526 & 4.747 \\
\hline $\begin{array}{c}\mathbf{2 0 1 0 - 2 0 1 6} \\
\left(\mathbf{M S W}^{*}\right)\end{array}$ & 11.617 & 4.747 & 453.044 & 4.747 & 27071.668 & 4.747 \\
\hline
\end{tabular}

\footnotetext{
${ }^{*}$ Municipal Solid Waste.
} 
In 2000-2009 (Fig. 2) there were changes in the amount of generated waste, and the influence of tourists and excursionists was less significant, which can be explained by the fact that at that time the statistical data did not take into account waste generated in households.

In 2010-2016 (Fig. 3) the amount of generated waste increased due to the growth of the number of tourists and excursionists, and GDP.

The amount of solid municipal waste was almost constantly increasing in 2010-2016 (Fig. 4), except for the decline in 2014, reflecting the presence of the influence of more factors.
Regression analysis of these data was also applied to determine the influence of the selected factors on the resultant indicator and the establishment of functional dependencies. The analysis of the influence of the selected factors on the amount of generated waste in Ivano-Frankivsk region allows us to assess the situation resulting from tourism activity during 2000-2016, and to forecast future amounts of waste generation.

We analyzed the results of regression analysis of statistical data on waste in 2000-2009 (Statistical data of Ivano-Frankivsk region, 2017; Waste management in Ukraine, 2017; Gross domestic product per capita, 2017; State Sta-

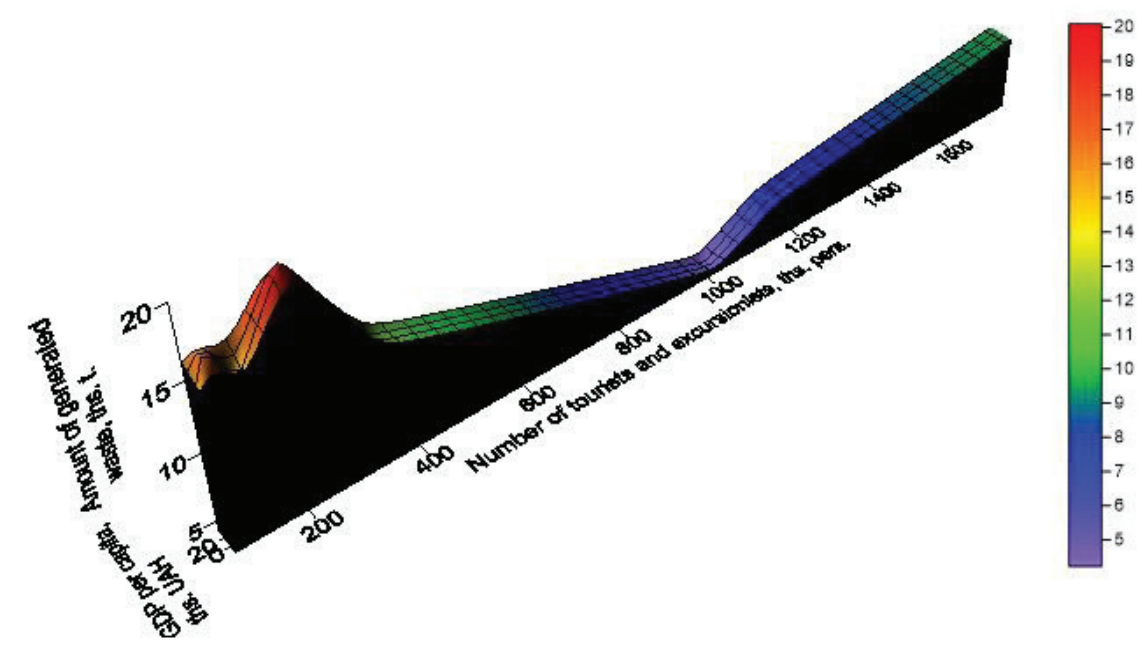

Figure 2. Process of waste generation in 2000-2009

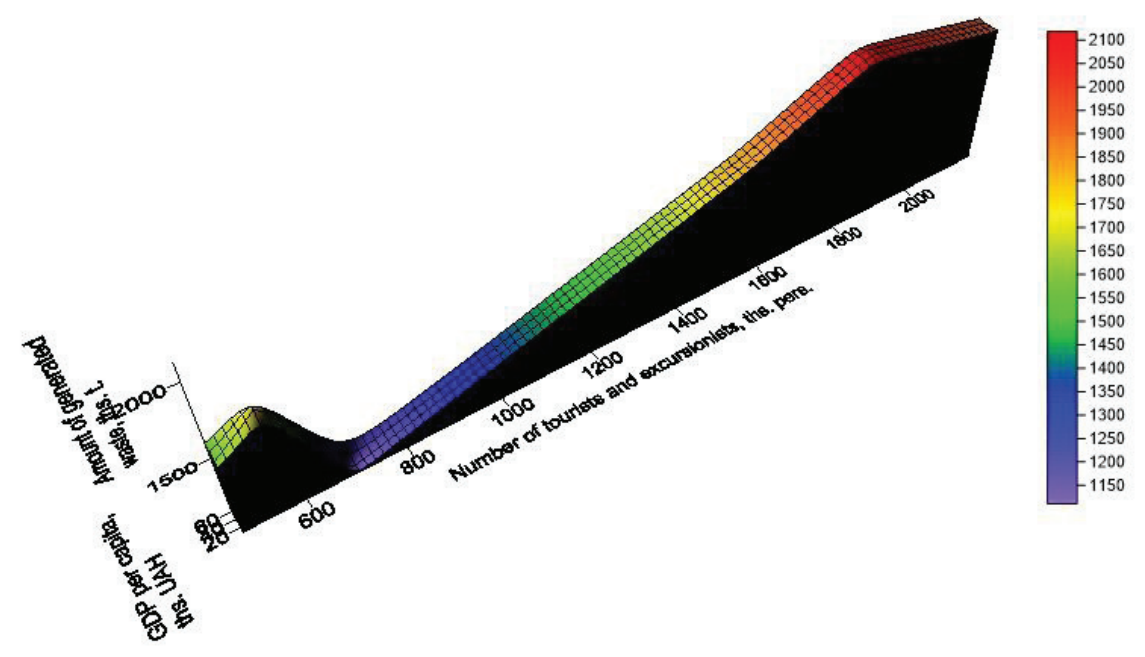

Figure 3. Process of waste generation in 2010-2016 


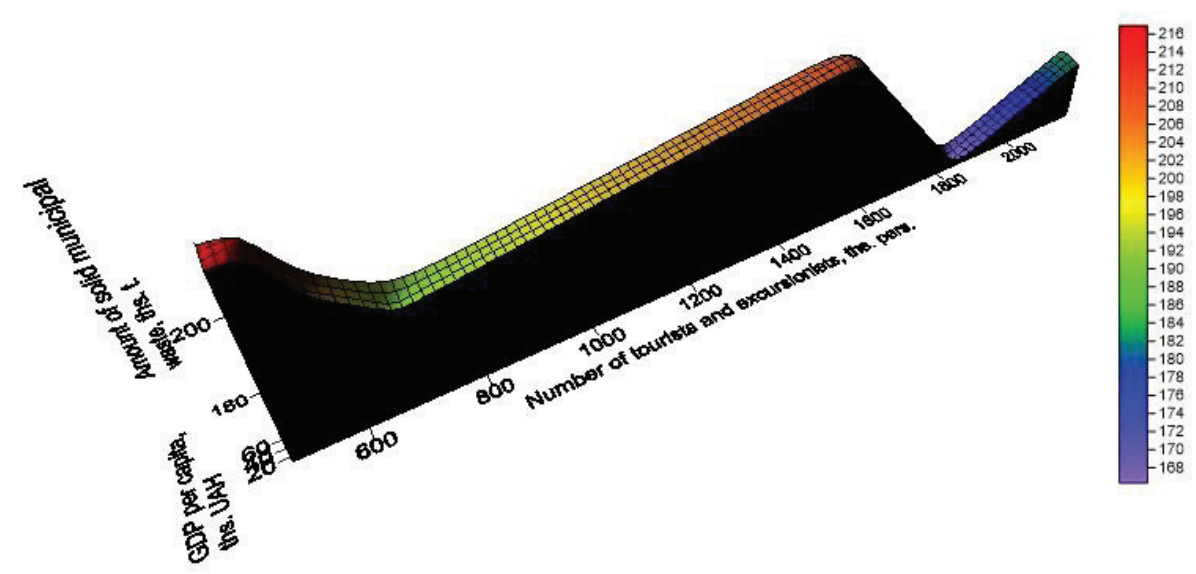

Figure 4. Process of municipal solid waste generation in 20102016

tistics Service of Ukraine, 2017). Complex data for regression analysis of the influence of factors on the amount of generated waste is given in Table 1.

The obtained multiple coefficient $\mathrm{R}=0.92$ confirms a strong connection between the resultant indicator and the factors. The coefficient $\mathrm{R}^{2}$ of the regression model is 0.846 . Therefore, the generated waste amount depends on the selected factors by $84.6 \%$.

As a result of applied three factor regression analysis the authors built the following mathematical model represented in Eq. (1):

$$
\mathrm{Y}=301.4-0.001 \mathrm{X}_{1}-1.23 \mathrm{X}_{2}-0.19 \mathrm{X}_{3}
$$

After normalization of the resultant and factors indicators the mathematical model obtained the following form represented in Eq. (2):

$$
\mathrm{Y}=14.70-0.09 \mathrm{X}_{1}-1.10 \mathrm{X}_{2}-13.78 \mathrm{X}_{3}
$$

The data for 2010-2016 is more significant, especially because of consideration of waste generated in households (Table 2) (Statistical data of Ivano-Frankivsk region, 2017; Waste management in Ukraine, 2017; Gross domestic product per capita, 2017; State Statistics Service of Ukraine, 2017).

The obtained multiple coefficient $\mathrm{R}=0.835$ confirms a strong connection between the resultant indicator and the factors. The coefficient $\mathrm{R}^{2}$ of the regression model is 0.64 . Therefore, the generated waste amount depends on the selected factors by $64.0 \%$.

As a result of applied three factor regression analysis the authors built the following mathematical model represented in Eq. (3):

$$
Y=-97888.1+0.06 X_{1}+17.96 X_{2}+71.64 X_{3}
$$

After normalization of the resultant and factors indicators the mathematical model obtained the following form represented in Eq. (4):

$$
\mathrm{Y}=-46.07+0.06 \mathrm{X}_{1}+0.40 \mathrm{X}_{2}+46.61 \mathrm{X}_{3}
$$

Since solid municipal waste is the most common type among waste within tourist destinations, the authors also applied a regression analysis for this type of waste (Table 3).

The obtained multiple coefficient $\mathrm{R}=0.868$ confirms a strong connection between the resultant indicator and the factors. The coefficient $\mathrm{R}^{2}$ of the regression model is 0.689 . Therefore, the generated waste amount depends on the selected factors by $68.9 \%$.

As a result of applied three factor regression analysis the authors built the following mathematical model represented in Eq. (5):

$$
\mathrm{Y}=-1810.97-0.03 \mathrm{X}_{1}+1.04 \mathrm{X}_{2}+1.45 \mathrm{X}_{3}
$$

After normalization of the resultant and factors indicators the mathematical model obtained the following form represented in Eq. (6):

$$
\mathrm{Y}=-8.31-0.09 \mathrm{X}_{1}+0.22 \mathrm{X}_{2}+9.24 \mathrm{X}_{3}
$$

\section{Conclusions}

Thus, by means of dispersion analysis the authors determined and justified that in tourist Ivano-Frankivsk region as a model one the significant factors affecting the amount 
of generated waste within tourist destinations are the number of tourists and excursionists, GDP per capita, number of population. The assessment of $3 \mathrm{D}$ dependencies in the process of waste generation within Ivano-Frankivsk region (Ukraine) in program Surfer allowed determining the level of interconnection between the factors of waste generation. As a result of the regression analysis of the dependence of the amount of generated waste on the selected factors, a strong connection was established between them, as indicated by a high coefficient $\mathrm{R}$ square $\left(\mathrm{R}^{2}=0.846\right.$; $\left.\mathrm{R}^{2}=0.64 ; \mathrm{R}^{2}=0.689\right)$. Their functional dependencies were established and they allow forecasting the amounts of waste generation within tourist destinations. Considering the growing tourist flows in recent years, solving of the issues of constantly increasing waste generation and the choice of efficient waste management methods within such territories is of great importance.

\section{References}

A Manual for Water and Waste Management, 2014, URL. http://www.unep.fr/shared/publications/pdf/WEBx0015xPA-WaterWaste.pdf.

Davies T. \& Cahill S., 2000, Environmental Implications of the Tourism Industry. Resources for the Future, Washington, DC.

Ezeah C., Fazakerley J. \& Byrne T., 2015, Tourism Waste Management in the European Union: Lessons Learned from Four Popular EU Tourist Destinations. American Journal of Climate Change 4: 431-445.

Gross domestic product per capita, 2017, URL. http://svspb.net/danmark/vvp-stran-na-dushu-naselenija.php.

Holden A., 2006, Environment and Tourism. Routledge, New York.

Holod A.P. \& Novosad Z.P., 2012, Ecological safety of tourism in the region: nature and ways of implementation. Naukovyi Visnyk NLTU Ukraiiny 22: 84-88.

Khajuria A., Yamamoto Y. \& Morioka T., 2010, Estimation of municipal solid waste generation and landfill area in Asian developing countries. Journal of Environmental Biology 31(5): 649-654.

Kotsiuba I.H., 2014, Mathematical forecasting of the amount of solid municipal waste generation in Zhytomyr. Bulletin of Poltava State Agrarian Academy 1: 102-105.

Mateu-Sbert J., Ricci-Cabello I., Villalonga-Olives E. \& Cabeza-Irigoyen E., 2013, The Impact of Tourism on
Municipal Solid Waste Generation: The Case of Menorca Island (Spain). Waste Management 33: 2589-2593.

Mihai F., 2013, Tourism implications on local waste management. Case study: Neamt County, Romania. Present Environment and Sustainable Development 7(1): 214-221.

Murava Iu. I. \& Korobeinykova Ia. S., 2016, The analysis of the waste problem on the example of the Carpathian region in Ukraine. Journal of Ecological Engineering, Poland, 2(17): 43-51.

Myronova T.L. \& Panova A.S., 2007, Ensuring of the ecological safety of socio-economic development of the Autonomous Republic of Crimea. Information technologies in the management of tourist and resort-recreational economy. Proceedings of the scientific and practical conference, Berdiansk: 79-80.

Nair Shibu K. \& Jayakumar C., 2008, A Handbookfor Waste Management in Rural Tourism Areas - A Zero Waste Approach. UNDP India, Archana. http://www.pgsi.org/ pdf/Handbook-on-Zero-Waste-UNDP-82672211.pdf.

Radwan H.R.I., Jones E. \& Minoli D., 2010, Managing solid waste in small hotels. Journal of Sustainable Tourism 18 (2): 175-190.

Sharko V.V., 2014, Ecological safety as an integral part of tourism development. Scientific Journal of Kherson State University 6(4): 113-116.

Sli B., 2000, The integration of sectoral policies on conservation of biological and landscape diversity: development of ecological tourism in Ukraine. Conservation and monitoring of biological and landscape diversity in Ukraine, Kyiv: 59-67.

State Statistics Service of Ukraine, 2017, URL. http:// www.ukrstat.gov.ua.

Statistical data of Ivano-Frankivsk region, 2017, URL. http://www.ifstat.gov.ua.

Vorobiova O.A., 2011, Ecological safety as a part of sustainable development of tourist and recreation areas. Sustainable development and ecological safety of society in the process of economic transformations. Proceedings of the 3rd Allukrainian science-and-practical conference, Bakhchysarai: 46-48.

Waste management in Ukraine, 2017, URL. http:// www.minregion.gov.ua/attachments/content-attachments/2732/1_.pdf

Zinko Y, Malska M., Ivanyk M. \& Blagodyr S., 2014, Tourism in the Carpathian region: threats to the environment and ways of sustainable development. Visnyk of Lviv University. Geographic series 45: 443-451. 